\title{
PERMAFROST AND PATTERNED GROUNDS IN FINLAND - PERIGLACIAL OR SOMETHING ELSE
}

\author{
AIMO KEJONEN
}

\begin{abstract}
AIMO KEJONEN, 1997: Permafrost and patterned grounds in Finland periglacial or something else. Bull. Geol. Soc. Finland 69, Part 1-2, 97-108.

Northernmost Finnish Lapland is periglacial. This area belongs to the zone of sporadic and alpine permafrost. Microclimatic permafrost can be found in eskers, caves and artifacts like mines everywhere in Finland. Periglacial permafrost occured in Southern Lapland and Ostrobothnia during some early Weichselian interstadial and at Salpausselkä zone and in the supra-aquatic parts of North Karelia during Yonger Dryas. Nowadays the Southern and Central Finland are no more periglacial.

Patterned grounds occur in all parts of Finland. Their number and species vary in different parts of Finland. In Northern Lapland the variety of patterned grounds is most polymorphous and sorted and nonsorted patterns are equally common. In Southern and Central Finland the big, sorted types like boulder depressions and sorted nets account for over $90 \%$ of patterned grounds. The processes forming patterned grounds are very active in Northernmost Lapland, but less active or fully fossilised in Southern Finland. The significance of local circumstances increases on the forming of patterned grounds in the south.
\end{abstract}

Keywords: periglacial features, permafrost, patterned ground, ice wedges, boulder depressions, genesis, Quaternary, Finland

Aimo Kejonen: Geological Survey of Finland, Regional Office for Mid-Finland, P.O.Box 1237, FIN-70211 Kuopio, Finland.

\section{INTRODUCTION}

In research, permafrost and patterned grounds are usually connected with periglacial conditions. However, the term "periglacial" is defined in many ways. Originally, it referred to the foreland conditions of a continental ice-sheet, where frost weathering (congelifraction) is strong and permafrost and patterned grounds form (Lodzinski 1909, V. Okko 1954, 1964, Taipale and Saarnisto 1994). The most comprehensive defining criteria were considered to be annual snow cover and freezing of the ground (Tricart \& Cailleux 1967). By strict definition, periglacial conditions are determined on the basis of climatic factors. A climate in which periclacial 
conditions prevail can be defined by the upper and lower limit of the annual average temperature, e.g. $-1--15^{\circ} \mathrm{C}$, or by the upper limit of the annual average temperature, e.g. under -2 ${ }^{\circ} \mathrm{C},-1{ }^{\circ} \mathrm{C}, 0{ }^{\circ} \mathrm{C}$ or $+3{ }^{\circ} \mathrm{C}$ and the amount of rainfall, e.g. $50-1250 \mathrm{~mm} / \mathrm{y}$, and/or according to the length of the thermal winter, e.g. over 210 days/y (Peltier 1950. Williams 1961, Fairbridge 1968, Embleton \& King 1975, French 1976, Washburn 1979).

According to different average temperature limits, the defined periglacial area in Finland varies greatly. Using the under $-1{ }^{\circ} \mathrm{C}$ limit, only the bare mountainous area above the treeline in Finnish Lapland is periglacial. Using under $0{ }^{\circ} \mathrm{C}$, the limit of the periglacial area runs through Kolari, Sodankylä and Salla in Lapland. Using under $+3{ }^{\circ} \mathrm{C}$, this area extends to Central Finland and North Karelia. According to Washburn (1979), the average temperature limit of $-1{ }^{\circ} \mathrm{C}$ best describes the border of the periglacial area. Permafrost and patterned grounds are more complicated phenomena than usually thought. There are several types of permafrost. Patterned grounds are a visible indicator of frozen grounds, which are most abundant and best developed in permafrost areas. However, they also develop under suitable conditions as the products of annual and, even, diurnal frost (Troll 1944, Washburn 1979).

\section{PERMAFROST IN FINLAND}

Permafrost has been known in Finland for 100 years (Kihlman 1890). Finland's only permafrost is considered to be ice inside palsas, which does not melt in summer (V. Okko 1964). The age, formation and development of the palsas have continually been the subject of scientific discussion (Auer 1927, Ruuhijärvi 1962, Kujansuu 1969, Salmi 1970a, 1970b, 1972, Seppälä 1976, 1979, 1983 and 1988). According to present understanding the development of palsas is cyclic. They form and melt all the time. Their development is regulated by the thickness of the snow cover and the bog peat layer. The palsas contain ice layers and at times a frozen mineral soil core. The world's first artificial palsa was made in Finland (Seppälä 1982). Frost resembling that present in palsas has been also found from a bog in Lapland, south of the palsa area proper (P. Hänninen 1995).

Although there had already been earlier hints of permafrost associated with mineral soils (Lagercrantz 1974), alpine permafrost has been found in the summit areas of the mountains of Finnish Lapland only during the last decade (King and Seppälä 1987, 1988). The permafrost layers are extensive in places. They comprise both unconsolidated earth and rock, and the frost may be over $50 \mathrm{~m}$ thick. These observations were confirmed when a well drilled at Yllästunturi was frozen to a depth of $40 \mathrm{~m}$ in summertime (Seppälä 1989). All sufficiently high sections above treeline in the mountains of Finnish Lapland have permafrost, from Saariselkä and Pallas-Ounastunturi northwards (Fig. 1). The lack of a snow blanket is important in the formation of alpine permafrost (King and Seppälä 1987). Snowbank glaciers have been found at Enontekiö during recent years (Hirvas 1991). Based on the previous, northernmost Lapland belongs to a zone of sporadic and alpine permafrost (Embleton and King 1975, Washburn 1979, Williams and Smith 1989). When the fall in average temperature caused by altitude is considered, the permafrost's border follows the limit quite well, with an annual average temperature of $-1^{\circ} \mathrm{C}$.

During the last decade observations were made of frost surviving over the summer. In North Finland, winter 1987 was exceptionally cold with little snow. While the frost layer in North Finland is normally $2-2.5 \mathrm{~m}$ thick, its thickness then was quite commonly 3-4 m. In September, frost preserved in the earth still caused the freezing of water pipes, south of Oulu and in Central Lapland. In ore exploration frost was found, in October - November 1987, at a depth of over $2 \mathrm{~m}$ at a locality where the land surface already had a $0.2-0.3 \mathrm{~m}$ frost layer (K. Nenonen, oral communication). In the exceptionally cold conditions, short-lived "perma- 
Aimo Kejonen 99

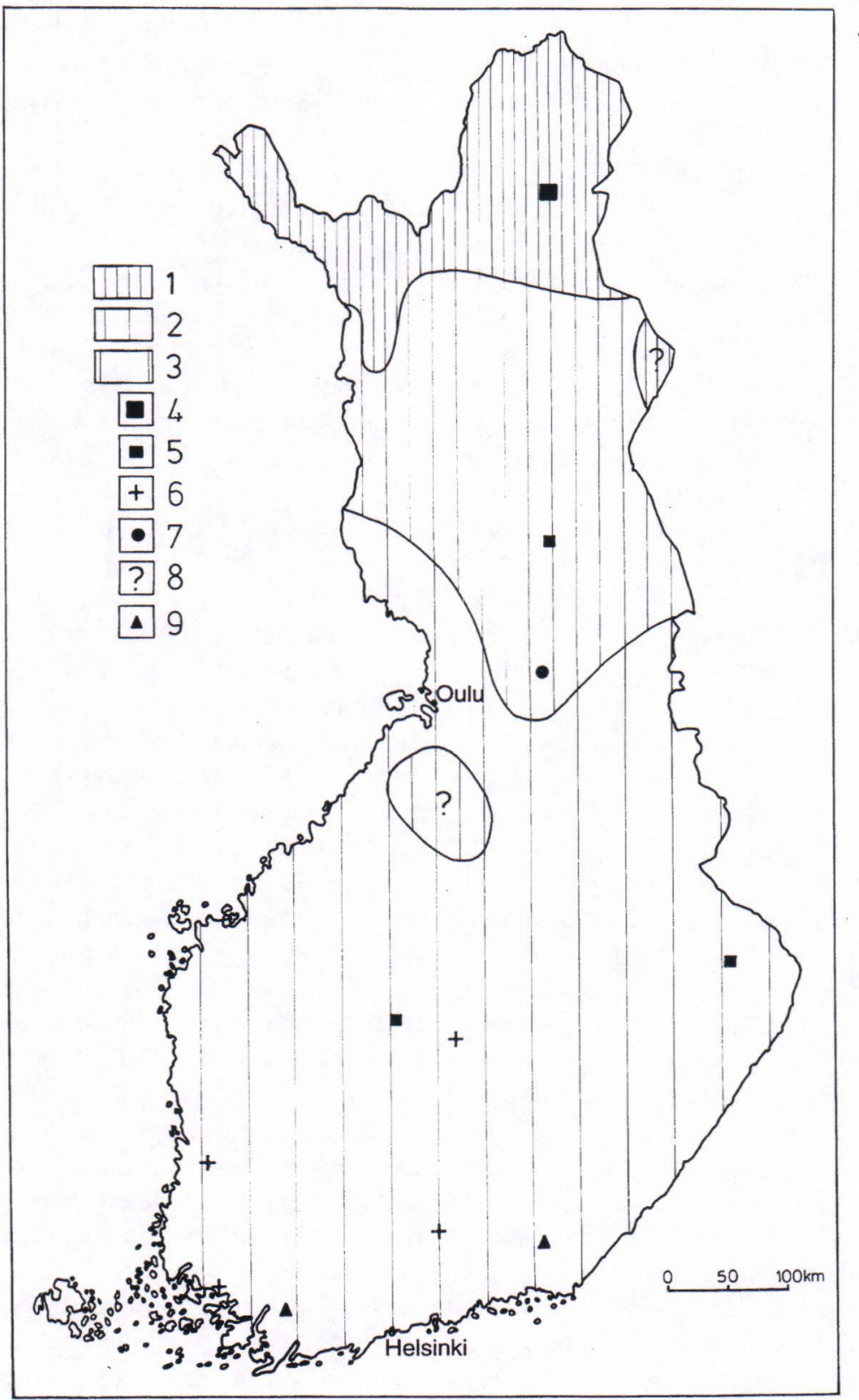

Figure 1. Finland's permafrost areas. 1. Area of sporadic and alpine permafrost. 2. Area of occasional frost surviving over one or some years. 3. Area of microclimatic permafrost. 4. Permanent permafrost in a cave. 5. Occasional frost surviving over one or some years in a cave. 6. Permafrost in an esker. 7. Palsalike permafrost outside the palsa area proper. 8. Uncertain area. 9. Permafrost in artifacts such as mines. 
frost" formed, lasting 1.5-2 years. However, only frost layers that survive many years are considered to be permafrost proper (Washburn 1979).

In South Finland, permafrost also occurs in eskers, caves and mines. The first observation from an esker was made in Turku at the turn of the century (Leiviskä 1914 and 1939).

Permafrost was found in eskers at Lahti and Laukaa (M. Okko 1969, Tynni 1972), and Äetsä (Fig. 1). Initially the permafrost and ice layers were considered to be remnants of a continental ice-sheet. At present they are explained by "esker breathing", in other words the product of the seasonal flow of air occurring in the eskers (V. Okko 1957). Sub-zero temperatures penetrating from the side into the esker form an internal cold store, which does not become warm enough in summertime. Enclosed earth materials and freezing leakage water form permafrost. V. Okko (1957) found "breathing eskers" at 28 localities. Ice and permafrost layers formed in caves and mines originate in a similar manner. In winter, sub-zero temperatures flow to their deepest parts, which do not get the opportunity to warm up during the summer (Kejonen et al. 1991). Observations over summer of preserved ice and frost were first made in the Aijala mine (Leiviskä 1939). In past years, a permanent natural icecave, a few caves and a Salpalinja WWII fortress, where during cold and dry years, ice and frost are preserved throughout the summer, have been discovered (Fig. 1). Permafrost originating in these types of protected places could be called microclimatic permafrost.

In different parts of Finland, as signs of ancient permafrost, are ice wedge casts, fossilised sorted polygons (Fig. 2), and layer disturbances called involutions (Aartolahti 1970, 1980, Ristiluoma 1974, Saarnisto 1977, Mäkinen 1985a, 1985b, 1996). The ice wedges of Lapland and Ostrobothnia are in till covered glaciofluvial formations. They originated during some interstadial of the Weichsel glaciation (Ristiluoma
1974, Mäkinen 1985a, 1985b, 1996). The ice wedges and involutions of the I and II Salpausselkä delta sands, and the ice wedges of the eskers of North Karelia (Fig. 2) originate at the end of the Weichsel glaciation. In North Karelia permafrost occurred in the supra-aquatic areas during the Younger Dryas. I have found ice wedges at Jaamankangas and Nurmes, on the eastern side of Kohtavaara. Other finds are at Lake Herajärvi on Kontiolahti, at Kaurilankangas and at Ruhka on Tohmajärvi, and at Raatevaara on the eastern part of Kiihtelysvaara (H. Rainio, oral communication). The late-glacial landslides of Lapland (Fig. 1) are connected to the melting of permafrost (Kujansuu 1972).

\section{PATTERNED GROUNDS IN FINLAND}

Patterned grounds are structures visible at the earth's surface, which are connected with processes that produce frost action. Their size and shape depend on the processes that form them, on their component material, and on inclination. Based on their morphology and material they are divided into sorted and nonsorted patterned grounds (Table 1). In sorted patterned grounds, stones and boulders are separate from more finer-grained earth. Earth materials, cracking of the ground, or vegetation, shape nonsorted patterned grounds. There is no consensus on what formations belong to patterned grounds. Some consider that sorted and nonsorted stripes, taluses (scree slopes), earth hummocks, solifuction sheets, tongues and steps and sedimentary structures, all produced by slope processes, are not patterned grounds. Others consider these and thermokarst lands originating from the melting of permafrost as patterned grounds (Embleton \& King 1975, Fairbridge 1968, Troll 1944, Washburn 1956, 1979). This study uses a broad classification of patterned grounds for simplification of the problem. 


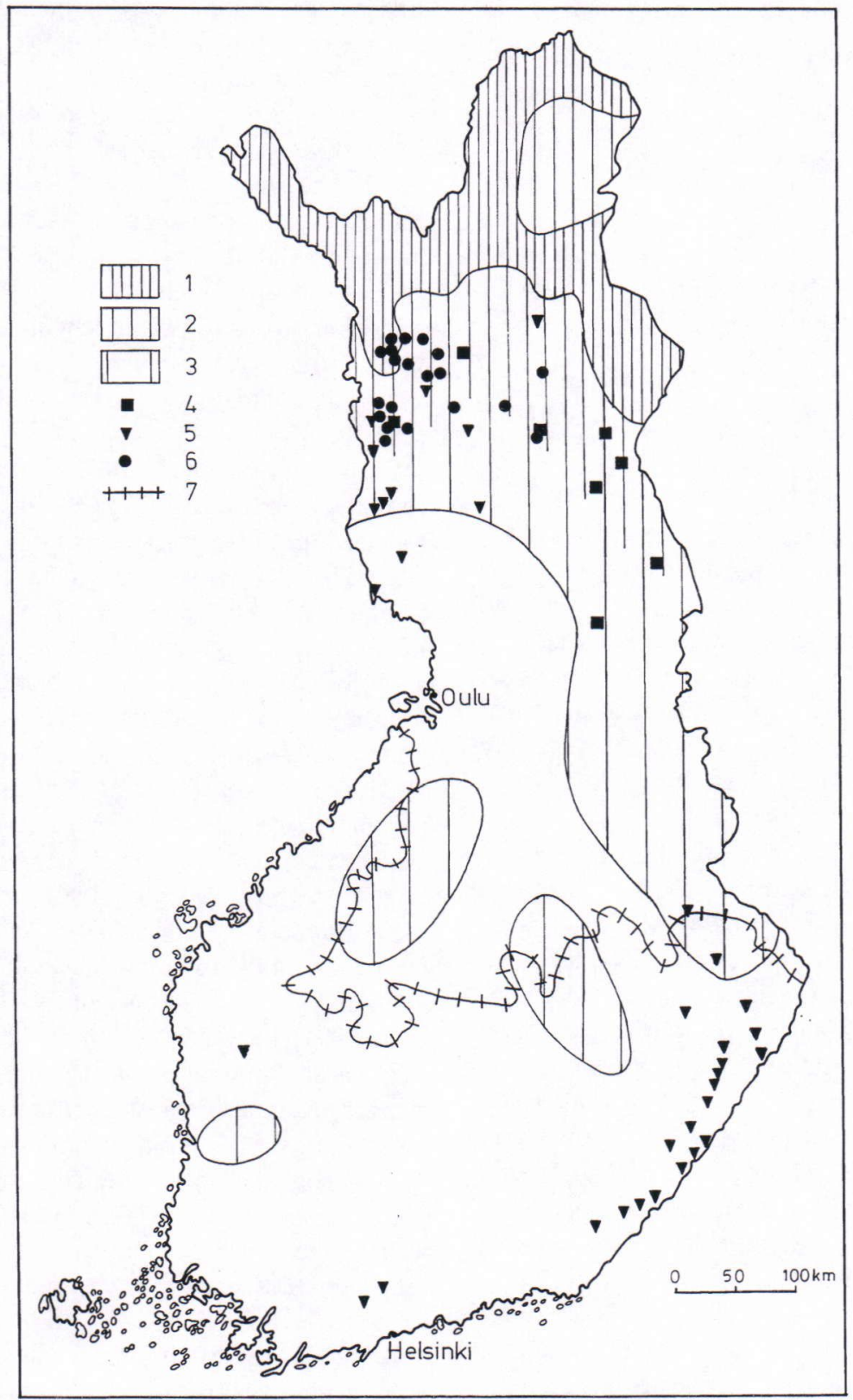

Figure 2. Finland's patterned ground areas. 1. Mountain area of Finnish Lapland, in which there is a complete variety of patterned ground types and their formative processes. 2. Southern Lapland, where there is a rich variety of patterned ground types, and in which their formative processes are partly active and sorted patterned ground types are emphasised. 3. The area of boulder depressions and other sorted patterned grounds. 4. Individual mountains, which belong to the mountain area of Finnish Lapland. 5. Ice wedge casts. 6. Land slides in Lapland. 7. Limit of area of raised and fen bogs. 
Table 1. Classification of patterned grounds.

\begin{tabular}{lll} 
Circles & Sorted & Nonsorted \\
Nets & Sorted & Nonsorted \\
Polygons & Sorted & Nonsorted \\
Terraces & Sorted & Nonsorted \\
Stripes & Sorted & Nonsorted \\
Steps & Sorted & Nonsorted \\
Tongues & Sorted & Nonsorted \\
Solifluction sheets & Sorted & Nonsorted \\
Boulder depressions & \\
\multicolumn{2}{l}{$\begin{array}{l}\text { Scree slopes (taluses) } \\
\text { Others }\end{array}$} & Sonsorted
\end{tabular}

There are patterned grounds everywhere in Finland. Their number and species vary in different parts of the country. In some areas patterned grounds form continually while elsewhere they, or some specific types, are fossils (Aartolahti 1980). In the treeless mountain areas of Finnish Lapland (Fig. 2) the variety of patterned ground types is nearly complete. This variety includes forms typical of permafrost areas, such as ice wedges, solifluction lobes and sorted stripes and nets (Tanner 1932, 1938, Okko, V. 1954, Ohlson 1964, Piirola 1969, 1972, Seppälä 1966, 1983, Kejonen 1979, 1984, 1994, Söderman 1980, Teider 1984, Hietaranta 1989, M. Hänninen 1994). In general, sorted and nonsorted patterned ground types are as extensive; however, local conditions cause noticeble alternation of patterned ground types (Piirola 1969, 1972, Söderman 1980). The processes that form these types are active all the time. It has been possible to study the formation of patterned grounds in detail (Söderman 1980, Kejonen 1979, 1994).

A transition zone outside the treeless mountain area of Lapland, southern Lapland and the Inari basin contains abundant patterned grounds formed by processes active under suitable conditions. The amount of the sorted patterned grounds, and their visibility increase southwards (Virkkala 1955, Kena 1957, Söderman 1980). Boulder depressions, taluses, sorted nets, circles and polygons are common. They are usually active. The most easily found nonsorted forma- tions are earth hummock nets (pounikko in Finnish) and earth islands belonging to nonsorted circles. Patterned grounds are concentrated in wet and weakly wooded areas such as on the edges of bogs, annual drying ponds and lake shores. The snow blanket and abundant vegetation are the most important factors that limit frost thickness and the occurrence of patterned grounds. Separate high treeless mountains such as Pyhätunturi form isolated areas in which patterned grounds are comparable to those of the treeless mountain areas of Northern Lapland (M. Hänninen 1994).

On the coast of the Gulf of Bothnia and from Kuusamo southwards (Fig. 2), the portion of fossilised, or at least very slowly developed patterned grounds, grows. Simultaneously the type variation of the patterned grounds changes. Sorted patterned grounds become dominant. In North Savo, North Karelia and North Ostrobothnia, they account for over $90 \%$ of patterned grounds (Aartolahti 1969, 1971, 1980, Karlsson 1979, Kejonen 1978, 1992, Lappalainen 1984). In favourable places, such as on shores, in caves and in places where snow and the vegetation are removed by man, nonsorted patterned grounds, earth hummocks, earth islands, frost cracks and gelifuction tongues may develop (Aartolahti 1969, 1970, 1971, 1980, Kejonen 1978, Kejonen et al. 1991, Lappalainen 1984). From Lapland southwards the assortment of patterned grounds changes. Boulder depressions, talus slopes and other large, sorted forms become more common at the expense of other types (Kejonen 1978 and 1992, Karlsson 1979). This may be apparent because the vegetation easily covers small patterned grounds making them impossible to observe.

Aartolahti (1980) considers the $+3{ }^{\circ} \mathrm{C}$ annual average temperature limit as the southern limit for the formation of patterned ground. It is approximately the same spot as the border between fen and raised bogs (Fig. 2). However, on the border's southern side, around Kullaan Isojärvi, besides other boulder field types, there are numerous boulder depressions. Nevertheless, the area only rose from the sea during the Ancylus- 
and Litorina periods, when there was little frost action. According to Söderman (1982), on the areas covered by the ancient great lakes SuurSaimaa and Muinais-Päijänne, there are many young boulder depressions that are less than 5000 years old. In contrast, the most active frost action occur in the treeless mountain areas of Finnish Lapland, which has an annual average temperature under $-1{ }^{\circ} \mathrm{C}$ (Kejonen 1979, 1994, Söderman 1980).

The significance of location increases in the south. On low shores, stone- and earth islands form and shore boulder fields develop into boulder depressions (Aartolahti 1969, 1970, Kejonen 1978, Söderman 1982, Lappalainen 1984). Earth hummocks may form on fields and logging areas. During spring and autumn, solifluction, needle-ice creep and boulder creep, and land and rock-slides occur in road cuts (Aartolahti 1969, 1980, Lappalainen 1984). Taluses develop in the Kuopio area at least (Kejonen 1978, 1993). Today, scree slopes develop in the Viipuri rapakivi area more than in adjoining areas of other rock types. A weathering rock type and the resulting precipices are favourable for the formation of scree slopes. Frost cracking develops in areas in which the snow covering is weak, or from which it has been removed (e.g. roads) (Aartolahti 1969, 1970, 1972, 1980, Lappalainen 1984). Around Kuopio, the rise of the road surfaces caused by frost is usually $5-20 \mathrm{~cm}$, even $70 \mathrm{~cm}$ in extreme cases (Lappalainen 1984). Annual layered frost may cause the formation of smallscale thermokarst (Kejonen 1984).

\section{DEVELOPMENT HISTORY OF PAT- TERNED GROUNDS}

In Lapland patterned grounds have been dated by separate methods. Their development history has beem established by studying patterned grounds and layered sucessions formed during their formation (Kejonen 1979, 1994, Mäkinen 1985a, 1985b, 1996, Ohlson 1964, Söderman 1980, Vliet-Lanoë et al. 1990). Frost action has also affected soil development (pedogenesis). In places in the mountain areas of Finnish Lapland there are arctic soils both on the present land surface and buried (cf. Tedrow 1977). These differ from the podzols usual in Finland.

The oldest patterned grounds in Lapland and Ostrobothnia developed during some Veiksel interstadial or early Veiksel stadial (Mäkinen 1985a, 1985b, 1996). They are in the glaciofluvial material of till-covered eskers and marginal formations. Next patterned ground formed in Lapland during deglaciation. and for some time after it. The climate warmed about 8000 BP. No patterned grounds formed, or their birth was rare, 5000-8000 years ago (Kejonen 1979, 1994, Söderman 1980). Then, most of the present treeless area was covered by forest (Eronen 1979, Eronen and Huttunen 1987). When the climate cooled, about 5000 years ago, patterned grounds began to form again and the summit areas became treeless. Relatively small falls in temperature, such as the Little Ice Age, already sped up patterned ground formation (Hietaranta 1989, Söderman 1980, Kejonen 1994). The present formation of patterned grounds is so fast that their development can be followed by measurement. Besides the cold climate, patterned grounds formed in the treeless mountain areas of Finnish Lapland are affected by the wind regulating the thickness of the snow cover, vegetation, vegetation destruction (e.g. by forest fires, insect destruction, or human activity, and by frost weathering (Seppälä 1981, Seppälä and Rastas 1980, Mattsson 1987).

Knowledge about the development of the patterned grounds of Central Finland and South Finland is incomplete. There was permafrost in the Salpausselkä zone and in the supra-aquatic areas of East Finland during the Younger Dryas. During this period ice-wedges and involutions formed (Aartolahti 1972, 1980, Saarnisto 1977). These are missing from subaquatic areas. New land rose from the sea at the end of the Ice Age, but permafrost no longer exists. Later, lake transgressions again drowned areas that were already dry. Patterned grounds still formed in these areas quite late. On the shores of the lakes Saimaa and Päijänne, boulder depressions occur in areas 
that were still covered by water $4000-5000$ years ago (Söderman 1982). Patterned grounds form under favourable circumstances in conditions still warmer than Finland's climate, such as in Gotland (Königsson 1966). They are caused by annual frost and also present-day activity.

Based on observations at Kivijärvi, at Kinnula and at Toholampi, part of the boulder prints depressions of North Ostrobothnia may be older than assumed. In places in which till has been excavated in construction of forestry roads, or in which a ditch was made through a boulder depression, a boulder bed is seen sagging under the till. In the buried boulder bed, the order of layers is typical of a boulder depression. The largest boulders are uppermost and the smallest stones are underneath. They have initially developed sometime during the Weichsel interstadial and have been preserved despite the glacial erosion. They are in the area of passive glacial erosion, from which abundant interglacial- and interstadial deposits have been found (Nenonen 1995). In Sweden and Norway, boulder depressions, boulder blankets and sorted nets have been described, which the glacier covered during the Veiksel glaciation (Nesje et al. 1988, Kleman and Borgström 1990, Hättestrand 1994). Glacial erosion has also varied by area in Finland, since there are tor-like weathering remnants older than the Ice Age in mountains in Lapland, in Ostrobothnia, and even around Kuopio (Kaitanen 1969, 1979, 1989, Söderman 1980, Söderman et al. 1983, Kejonen 1993).

\section{CONCLUSIONS}

The information presented above on Finland's permafrost and patterned grounds presentations can be summarised in the following six statements:

1. Northernmost Lapland and the treeless mountain zone in particular are periglacial areas, with sporadic and alpine permafrost. Palsas occur in the area and there are permafrost layers in mineral earth and rock in the summit area of the mountain zone. The layers can even be sev- eral tens metres thick and tens of hectares wide. The range of patterned grounds is almost complete. It corresponds to the variety of patterned ground types met in other periglacal areas. Sorted and nonsorted patterned grounds are equally common. Processes forming patterned grounds are continually active.

2. On the southern side of the periglacial zone is a zone comprising South Lapland and part of North Ostrobothnia, in which, after exceptionally cold winters with little snow, periglacial features form. The area's bogs may contain palsa-like frost formations. In exceptionally cold winters with little snow, permafrost layers that last over the following summer, or for a couple of years, form in mineral earths. These can not be considered to be actual permafrost, rather they are a form intermediate between permafrost and annual frost. The proportion of sorted patterned grounds increases with southward movement. In places suitable for frost action, annual frost develops patterned grounds in the manner of permafrost.

3. Central and South Finland do not belong to the present-day periglacial zone, although in places the area contains abundant patterned grounds. The patterned grounds locally abundant in some areas are mainly unsorted types. Most of the patterned grounds are fossilised, at least in the southern part of the area. Annual frost forms patterned grounds, in the manner of permafrost, on areas very favourable for frost action.

4. Throughout Finland, microclimatic permafrost may form in suitable places such as in eskers, in caves and in mines. This permafrost is not periglacial, rather it is the result of the retention of winter cold in the earth, caves, or mines. This permafrost type is not significant in the formation of patterned grounds, and can be called microclimatic permafrost.

5. In Finland, there was periglacial permafrost during the interstadial period of the last ice age and on supra-aquatic areas during the melting phase of the continental ice. Ice wedge casts and involutions representing signs of ancient permafrost occur at Salpausselkä and in 
North Karelia, Ostrobothnia and Lapland. The ice wedge casts of Salpausselkä and North Karelia are late glacial. The ice wedge casts of Lapland are covered by till blankets formed during some interstadial of the Veiksel glaciation.

6. The formation of patterned grounds is totally bound to climatic change; however, local conditions have a significant effect. Solifluction and other slope processes were at a standstill during the temperature optimum. In cold periods, frost action restarts quickly. Even in Lapland, but particularly in Central and Southern Finland, patterned grounds form in places from which some factor (e.g. coastal forces, forest fire, man or animals) has destroyed the snow cover, or vegetation, preventing frost action. 


\section{REFERENCES}

Aartolahti, T. (1969) On patterned ground in southern Finland. Annales Academiae Scientiarum Fennicae. Ser. A III:104, 1-30.

Aartolahti, T. (1970) Fossil ice-wedges, tundra polygons and recent frost cracks in southern Finland. Annales Academiae Scientiarum Fennicae A III 107.

Aartolahti, T. (1971) Etelä-Suomen louhikoista. Terra 83:2, 74-80

Aartolahti, T. (1972) Dyynien routahalkeamista ja halkeamapolygoneista. Terra 84:3, 124-131.

Aartolahti, T. (1980) Periglasiaalisen morfologian tutkimus Suomessa (The research of periglacial morphology in Finland). Terra 92:2, 74-87.

Auer, V. (1927) Untersuchungen über die Waldgrenzen und Torfböden in Lappland. Communicationes Instituto Quaestionarum Forestalium Finlandiae 12:4.

Embleton, C. \& King, C. A. M. (1975) Periglacial geomorphology. Edward Arnold Ltd, London. 203 s.

Eronen, M. (1979) The retreat of pine forests in Finnish Lapland since the Holocene climatic optimum: a general discussion with radiocarbon evidence from subfossil pines. Fennia 157:2, 93-114.

Eronen, M. \& Huttunen, P. (1987) Radiocarbondated subfossil pines from Finnish Lapland. Geografiska Annaler 69 A:2, 297-304.

Fairbridge, R. W. (ed.) (1968) The Encyclopedia of Geomorphology. Encyclopedia of earth sciences series, volume III. Reinhold Book Corp. New York - Amsterdam - London. 1295 p.

French, H. M. (1976) The periglacial environment. Longman, New York. 309 p.

Hellemaa, P. (1991) Tuulen vaikutus deflaatioon ja lumen kinostumiseen Kilpisjärven alueella (Winds causing deflation and snow-drifting in Kilpisjärvi area). Terra 103:4, 309-316.

Hietaranta, J. (1989) Kevojoen laakson pahtarinteiden rapautumisesta ja taluskeilojen post-glasiaalisesta kehityksestä. Esimerkkeinä Kotka- ja Könkapahdan keilat. Julkaisematon progradu tutkielma. Maantieteen laitos, Turun yliopisto. $67 \mathrm{~s}+11$ liites.

Hirvas, H. (1991) Meilläkin jäätikkö. Tiede 2000. 6/1991, 59.

Hänninen, M. (1994) Pelkosenniemen Pyhätunturin geomorfologia. Julkaisematon pro gradu. Maantieteen laitos. Oulun yliopisto. $111 \mathrm{~s}$.
Hänninen, P. (1995) Pudasjärvellä Suomen eteläisin "palsa". Geologi 47:6, 75-78.

Hättenstrand, C. (1994) Boulder depressions in central Sweden - remnants of a pre-late weichselian landscape? Geografiska Annaler 73A:3, 153-160.

Kaitanen, V. (1969) A geographical study of the morphogenesis of northern Lapland. Fennia 99:5. $85 \mathrm{p}$.

Kaitanen, V. (1979) Composition and morphotectonic interpretation of the Kiellajohka drainage basin, Finnish Lapland. Fennia 140. 54 p.

Kaitanen, V. (1989) Relationships between ice sheet dynamics and bedrock relief in dissected plateau areas in Finnish Lapland north of $69^{\circ}$. Geografiska Annaler 71 A:1, 1-15.

Karlsson, K.-P. (1979) Toholammin alueen louhikot. Julkaisematon Pro gradu-tutkielma. Maantieteen laitos. Helsingin yliopisto. 78 p.

Kejonen, A. (1978) Kuopion alueen louhikot. Julkaisematon laudaturtyö. Maantieteen laitos, Turun yliopisto. $91 \mathrm{p}$.

Kejonen, A. (1979) Vuotomaista Muotkatunturien alueella Pohjois-Lapissa (On solifluction sediments in the Muotkatunturit area, Northern-Lappland). Turun yliopiston maaperägeologian osaston julkaisuja 40.43 p.

Kejonen, A. (1984) Havainto vuosittaisen roudan aiheuttamasta minitermokarstista Teiskossa. Geologi 36:5, 89-90.

Kejonen, A. (1993) Pohjois-Savon louhikot. Savon luonto. Vuosikirja 1993. 24, 14-20.

Kejonen, A. (1994) Nykyinen ja muinainen vuotomaatoiminta Muotkatunturien ja Ailikkaan alueilla Lapissa. (Present and ancient solifluction in the Muotkatunturit and Ailigas areas Finnish Lapkand). In: Perttunen, M. (ed.) 1994. Uudet menetelmät ja niiden sovellutukset kvartääritutkimuksessa. Symposio Mekrijärvellä 20-21.4. 1993. Acta Universitatis Ouluensis. Series A. Scientiae rerum naturalium $251,43-57$.

Kejonen, A., Kielosto, S. \& Salonen, V.-P. (1991) Ikiroutaa ja kuviomaita Suomen luolissa (Summary: Permafrost and patterned grounds in Finnish caves). Geologi 43:7, 134-141.

Kihlman, A.O. (1890) Pflanzenbiologische Studien aus Russisch Lappland. Acta Societas Fauna et Flora Fennica 6:3, 1-63.

King, L. \& Seppälä, M. (1987) Permafrost Thickness and Distribution in Finnish Lapland - Results of Geoelectrical Soundings. Polarforschung 57:3, 127-147. 
King, L. \& Seppälä, M. (1988) Permafrost sites in Finnish Lapland and their environment. (Reprint) Proceedings of $\mathrm{V}$ international conference of permafrost, Trondheim - Norway, 183-188.

Kena, A. (1957) Kuviomaat Laanilan ympäristössä. Julkaisematon pro gradu. Maantieteen laitos. Helsingin yliopisto. $57 \mathrm{p}$

Kleman, J. \& Borgström, I. (1990) The boulder fields Mt. Fulufjället, west-central Sweden -Late Weichselian boulder blankets and interstadial periglacial phenomena. Geografiska Annaler 72A:1, 63-78.

Kujansuu, R. (1969) Palsoista ilmakuvatulkinnan valossa. Geologi 21, 1-4.

Kujansuu, R. (1972) On landslides in Finnish Lappland. Geological Survey of Finland, Bulletin 256. $22 \mathrm{p}$.

Königsson, L.-K. (1966). Stenströmmar och utdragna polygoner på Gotland. Extrazonala frostjordfenomen i en sluttning. Geologiska Föreningens i Stockholm Förhandlingar 88:3, 404-407.

Lagergrantz, C.-L. (1972) Om den glaciala erosionen i Kilpisjärvi sjöbäcken. Terra 86:4, 175-180.

Lappalainen, L. (1984) Roudan aiheuttamat geomorfologiset muodostumat ja roudan vaikutus ihmisen toimintaan Länsi-Savossa. Julkaisematon pro gradu. Maantieteen laitos. helsingin yliopisto. 103 p.

Leiviskä, I. (1914) Kivinen jääkerros sorakukkulassa lähellä Turkua. Suomalainen tiedeakatemia. Esitelmät ja pöytäkirjat $1913 \mathrm{II}, 73-84$.

Leiviskä, I. (1939) Turun Myllymäen jääkerros. Suomalainen tiedeakatemia. Esitelmät ja pöytäkirjat 1937, 87-99.

Lodzinski, M. W. (1909) On the Mechanical Weathering of Sandstones in Temperate Climate. In: Evans, D.J.A. (ed.) 1994. Cold climate landforms. John Wiley \& Sons, Chichester - New York Brisbane - Toronto - Singapore. 119-134.

Mattsson, J. (1987) Ihmisen vaikutus Utsjoen metsänrajametsiin. Julkaisematon pro-gradu tutkielma. Maantieteen laitos, Turun yliopisto. $123 \mathrm{p}$.

Mäkinen, K. (1985a) Site 17. Interstadial deposits at Orajärvi, Pello. In: Saarnisto, M. (ed.). 1985. INQUA till symposium, Finland 1985. Excursion guide. Geological Survey of Finland, Department of Quaternary Geology. Espoo, 112.

Mäkinen, K. (1985b) On the Till-Covered Glaciofluvial Formations in Finnish Lapland. In: Glaciofluvium (L.-K. Königsson, Ed.). Striae 22, 33-40.

Mäkinen, K. (1996) Lapin jääkiiloista. In: Periglasiaaliset ilmiöt ja ympäristön muutos Suomessa symposio 25-26.10.1996. Siuntio, Helsinki: Suomen kvartääritutkimuksen kansalliskomitea, 11.
Nenonen, K. (1995) Pleistocene stratigraphy and reference sections in Southern and Western Finland. Academic dissertation. Geological Survey of Finland. Regional Office for Mid-Finland. 205 p.

Nesje, A., Dahl, S. O., Anda, E. and Rye, N. (1988) Block fields in southern Norway: Significance for the Weichselian ice sheet. Norsk Geologisk Tidskrift $68,149-170$.

Ohlson, B. (1964) Frostaktivität, Verwitterung und Bodenbildung in den Fjeldgegenden von Enontekiö, Finnisch-Lappland. Fennia 89:8, 1-180.

Okko, M. (1969) Pysyvä jääkerros harjuaineksessa lähellä Lahtea. Edeltävä tiedonanto (Summary: Perennial ice layer in glaciofluvial drift near Lahti, Southern Finland. Preliminary report). Geologi 21:7, 108-109.

Okko, V. (1954) Periglasiaalisesta morfologiasta Suomessa. Terra 66:2, 54-57.

Okko, V. (1957) On the thermal behaviours of some Finnish eskers. Fennia 81:5. $38 \mathrm{~s}$.

Okko, V. (1964) Maaperä, 239-332. In: Rankama, K. (ed.). Suomen geologia. Helsinki. 414 p.

Peltier, I. C. (1950) The geographic cycle in periglacial regions as it is related to climatic geomorphology. Association American Geographical Annals 40, 214-236.

Piirola, J. (1969) Frost-sorted block concentrations in western Inari, Finnish Lapland. Fennia 99:2,

Piirola, J. (1972) The Inari region of Finnish Lapland. Fennia 111. 86 p.

Ristiluoma, S. (1974) Fossiilisia jääkiiloja Tornionjokilaaksossa. Terra 86:1, 3-6.

Ruuhijärvi, R. (1962) Palsoista ja niiden morfologiasta siitepölyanalyysin valossa. Summary. Über die Palsamoore und dereb Morphologie im Lichte der Pollenanalyse. Terra 74:2, 58-68.

Saarnisto, M. (1977) Deformational structures in the first Salpausselkä end moraine, Joutsenonkangas, South-Eastern Finland. Bulletin of the Geological Society of Finland 49, 65-72.

Salmi, M. (1970a) Investigations on palsas in Finnish Lapland. Proceedings of UNESCO symposium on the ecology of subarctic regions, Otaniemi (Helsinki), Finland 1966, 143-153.

Salmi, M. (1970b) Development of palsas in Finnish Lapland. Proceedings of the Third International Peat Congress, Quebec, Canada 1968, 182-189.

Salmi, M. (1972) Present developmental stage of palsas in Finland. Proceedings of the 4th International Peat Congress, Finland 1972, 121-141.

Seppälä, M. (1966) Recent ice-wedge polygons in eastern Enontekiö, northernmost Finland. Pub- 
licationes Instituti Geographici Universatitis Turkuensis $42,14 \mathrm{p}$.

Seppälä, M. (1976) Seasonal thawing of a palsa in Enontekiö, Finnish Lapland in 1974. Biuletyn Peryclacjalny $26,17-24$.

Seppälä, M. (1979) Recent palsa studies in Finland. In: Vasari, Y., Saarnisto, M. and Seppälä, M. (eds) 1979. Paleohydrology of the temperate zone. Acta Universatitis Ouluensis Ser. A 82:3, 81-87.

Seppälä, M. (1981) Forest fires as activator of geomorphic processes in Kuttanen esker-dune region, northernmost Finland. Fennia 159:1, 221-228.

Seppälä, M. (1982) An experimental study of the formation of palsas. Proceeding of the Fourth Canadian Permafrost Conference Calgary, Alberta, March 2-6 mars 1981, 36-42.

Seppälä, M. (1983) Present day periglacial phenomena in northern Finland. Publicationes Instituti Geographici Universatitis Helsingiensis A 125.42 p.

Seppälä, M. (1986) The origin of palsas. Geografiska Annaler 68A:3, 141-147.

Seppälä, M. (1988) Palsas and related forms. In: M. J. Clark (ed.) 1988. Advances in periglacial geomorphology. John Wiley \& Sons Ltd, Chichester. 247-278.

Seppälä, M. (1989) Kun Suomesta löytyi paljon ikiroutaa. Tiede 2200 N:o 2, 65.

Seppälä, M. \& Rastas, J. (1980) Vegetation map of northernmost Finland with special reference to subarctic forests limits and natural hazards. Fennia 158:1, 41-61.

Söderman, G. (1980) Slope processes in cold environments of Northern Finland. Fennia 158:2, 83152.

Söderman, G. (1982) Södra Finlands blocksänkor. Geografisk Tidskrift 82, 77-81.

Söderman, G., Kejonen, A. \& Kujansuu, R. (1983) The riddle of the tors at Lauhavuori, western Finland. Fennia 161:1, 91-144.

Taipale, K. \& Saarnisto, M. (1991) Tulivuorista jääkausiin. Suomen maankamaran kehitys. WSOY. Porvoo - Helsinki - Juva. 416 s.
Tanner, V. (1932) Zur Deutung der Genesis des ausgeebneten Reliefs der Hochflächen und Widden in Fennoscandia. Bulletin de la Commision geologique de Finlande 97, 40-51.

Tanner, V. (1938) Die Oberflächengestaltung Finnlands. Bidrag till kännedom af Finlands natur och folk $86.762 \mathrm{p}$.

Teider, R. (1984) Sarvisoaivin tunturialueen periglasiaalinen morfologia. Julkaisematon pro gradu. Maantieteen laitos. Helsingin yliopisto. $72 \mathrm{~s}$.

Tedrow, J. C. F. (1977) Soils of the polar landscape. Rutgers university press, New Brunswick, New York. 638 p.

Tricart, J. \& Cailleux, A. (1967) Le modéle des régions périglaciaires. Traité de Géomorphologie 2. Paris, SEDES. $512 \mathrm{p}$.

Troll, C. (1944) Struckturböden, Solifluction und Frost-Klimate der Erde. Geologische Rundschau 34, 545-694.

Tynni, R. (1972) Ympärivuotisesti jäätynyt glasifluviaalinen kerrostuma Laukaalla (Summary: A semi-permanently frozen glaciofluvial deposit in Laukaa). Geologi 24:4, 47-48.

Washburn, A. L. (1956) Classification of patterned ground and review of suggested origins. Geological Society of American Bulletin 67, 823-866.

Washburn, A. L. (1979) Geocryology. A survey of periglacial processes and environments. Edward Arnold Ltd, London. 406 p.

Williams, P. J. (1961) Climatic factors controlling the distribution of certain frozen ground. Geografiska Annaler 43A:2, 339-347

Williams, P. J. \& Smith, M. W. (1989) The Frozen Earth. Fundamentals of geocryology. Cambridge university press, Cambridge. $306 \mathrm{p}$.

Virkkala, K. (1955) On glaciofluvial erosion and accumulation in the Tankavaara area, Finnish Lapland. Acta Geografica 14, 393-412.

Vlinet-Lanoë, B. V., Seppälä, M. \& Käyhkö, J. (1990) Cryoturbation features controlled by Holocene drainage change. Hietatievat dune field, Finnish Lapland. Notes compte-rendus du groupe de travail regionalisation de periglaciaire $15,61-66$. 